Open Access

\title{
Relationships of managers' entrepreneurial perception and internationalization speed in small and medium-sized enterprises (SMEs)
}

Samaneh Saghebi ${ }^{1}$, Abolfazl Alizadeh ${ }^{2,3^{*}}$, Mohammad Mohammadzaheri ${ }^{2}$ and Tahmineh Habibisenobari ${ }^{4}$

\author{
* Correspondence: alizadeh.ab@fc.lu. \\ ac.ir \\ ${ }^{2}$ Lorestan State University, \\ Khorramabad, Iran \\ ${ }^{3}$ Tehran, Iran \\ Full list of author information is \\ available at the end of the article
}

\begin{abstract}
International entrepreneurship literature has been taken into account by researchers since the late 1980s, and they have investigated how entrepreneurs behave according to different aspects, how some of them succeed in international markets, and others fail to continue. Therefore, the present research investigated the entrepreneurial behavior as well as relationships of managers' entrepreneurial perception and the internationalization speed (IS) in small and medium-sized enterprises (SMES). The statistical population consisted of managers in SMEs in an active Iranian industrial estate that has taken international measures. Hypotheses were tested using the structural equation test and LISREL software by analyzing 320 correct questionnaires. The obtained results indicated that the entrepreneurs' international orientation $(I O)$ had a significant relationship with the proactivity (PR), tolerance of ambiguity (TA), knowledge intensity (KI), and risk perception (RP). They also confirmed significant relationships of the knowledge intensity, risk perception and the internationalization speed, but no relationship was found between the tolerance of ambiguity and risk perception.
\end{abstract}

Keywords: Internationalization speed (IS), Entrepreneurial behavior, Risk perception $(\mathrm{RP})$, Proactivity (PR), Tolerance of ambiguity (TA)

\section{Introduction}

Research on different aspects of globalization phenomenon have been accelerating since the 1980s. In this regard, there are young and entrepreneurial firms which are seeking to attract customers in global markets. Researchers have named them born global firms (Cavusgil and Knight 2015; McDougall-Covin et al. 2014; Gruber and MacMillan 2017). The first entrepreneurship orientation analysis was performed by Miller and Friesen (1983) that he investigated the entrepreneurship orientation according to the innovation, risk taking, and proactivity (Hernandez-Perlines 2018). According to definitions of the international entrepreneurship, there are four points namely "the discovery," "approval of opportunities," "evaluation," and "utilization of opportunities" in order to create goods and services in the future (Oviatt et al. 2004: 540; Terjesen et al. 2016). It can be concluded that the development of products and markets for their higher

(C) The Author(s). 2019 Open Access This article is distributed under the terms of the Creative Commons Attribution 4.0 International License (http://creativecommons.org/licenses/by/4.0/), which permits unrestricted use, distribution, and reproduction in any medium, provided you give appropriate credit to the original author(s) and the source, provide a link to the Creative Commons license, and indicate if changes were made. 
profitability and sales is a goal of international entrepreneurship in companies that needs high speed implementation. McDougall and Oviatt (2000) considered the international entrepreneurship as a combination of innovative, progressive, and risk-taking behavior that sought to create values for companies outside borders of a country. In a more comprehensive definition, the international entrepreneurship is defined as "the discovery, approval, evaluation and utilization of opportunities across national borders to create future goods and services" (Oviatt and McDougall 2005a). Entrepreneurs play important roles in born global firms. Cantillon (1755) called entrepreneurs the risk takers. They are the main decision makers in businesses and make final decisions along with rational risk (Ely and Hess 1893: 95; Brustbauer 2016). These entrepreneurs have special characteristics (Matviuk 2010: 65). These characteristics, attitudes, and values distinguish them from others (Gürol and Atsan 2006: 28; Gruber and MacMillan 2017). Gruber and MacMillan (2017) sought to provide entrepreneurial characteristics enjoying a research by McGrath and MacMillan $(2000,2)$ and stated that on the contrary to other people, the entrepreneurs invest in the uncertainty, utilize simplicity instead of the complexity, their learning is resulted from their rational risk-taking, and they are always seeking for solutions.

Entrepreneurs, who work in small and medium-sized businesses, are faced with complicated challenges since due to the lack of available resources to such companies, they do not have high freedom of action and exposed to higher risk to enter international markets unlike large companies. New firms, which quickly enter international markets, have features such as "innovative behavior," "risk taking," and "proactivity" that can be decisive for identifying them because these types of behavior reveal how their internationalization is speeding up (Acedo and Jones, 2007). Meanwhile, managers and entrepreneurs' willingness is another determinant of the higher speed of internationalization (Harveston et al. 2000; Nummela et al. 2005; Acedo and Jones, 2007).

These constraints, with which such businesses are faced, have negative effects one of which is the lack of presence in international markets because they are afraid of failures; and the lack of access to sufficient funds, more limited facilities, limited access to market research, and the inability to recruit experts compared to larger firms put pressure on them (Knight and Liesch 2002; Musteen et al. 2010). On the other hand, this internationalization also brings benefits including an increase in company learning and increased opportunities (Zahra and Hayton 2008). Learning is accelerated when companies are at early stages of development due to their flexible structure, and this adaptability is more facilitated; thus, they quickly recognizes available opportunities in other markets (Autio et al. 2000; Weerawardena et al. 2007; Musteen et al. 2010).

Small and medium-sized businesses account for most sectors of companies, for instance, $97 \%$ of export companies in the USA are these businesses. They own nearly one third of the US export value (Brookings Institution 2012, p. 7). This is 90\% in Iran, the Iranian companies account for only $10 \%$ of export (Samt newspaper 2013). According to the comparison of statistics, such companies play minor roles in exports (as a way of internationalization) in Iran, and this requires conducting studies on its reason. Researchers have found that studies have been conducted in other countries including America and Australia (Business Week 1992; McKinsey and Company 1993) which have studied born global firms. For instance, Harveston et al. (2000) studied 224 firms according to differences of born global firms and gradual globalizing from the individual perspective and found that managers of born global 
firms had higher risk tolerance and higher international experience. Nummela et al. (2004) also considered managers' global mentality to be a reason for better international performance of these companies. Byer et al. (1997) analyzed more than 50 studies that identified six characteristics for entrepreneurs including high opportunism, risk tolerance, ambiguity, adaptability, and motivation. However, there are a few studies on the Iranian companies; hence, the present study investigated relationships of international orientation, proactivity, tolerance of ambiguity, knowledge intensity, risk perception, and internationalization speed among small and medium-sized enterprises (SME) of Iran.

\section{Research background and theoretical framework}

Psychological and cognitive factors in international entrepreneurship affecting the speed of internationalization

Several factors play important roles in the inclusion in international markets and accelerating this process as researchers have examined it from different perspectives (Chen and Huang 2004). Changes in circumstances have emerged a situation where small and medium-sized enterprises play large, diversified, and important roles in the growth of developing countries (Kula and Tatoglu 2003). Many barriers to the development of these companies have been eliminated after the globalization phenomenon; thus, international entrepreneurs may focus on a wider range beyond their own borders (Etemad and Wright 2003). Given that the export is a method of internationalization, Robertson and Chetty (2000) found that export entrepreneurs were better than other exporters in turbulent environments. Bhuian et al. (2005) also found that the entrepreneurial behavior enabled companies to lead the market. This behavior enables companies to feel and select new opportunities in their preferred markets.

It is in fact complicated to understand how an entrepreneurial process is formed and what factors are involved in it (Baron and Ward 2004; Krueger 2003; Mitchell et al. 2000). In this regard, entrepreneurs' mental factors are involved in their decision-making. The emergence of research on psychological aspects of the internationalization process dates back to the 1970s, which studies by Bilkey and Tesar (1977), Cavusgil and Nevin (1981), and Wiedersheim-Paul et al. (1978) focused on this issue that stated under similar conditions individuals made different choices were based on their mental factors (Eisenhardt and Schoonhoven 1990), and thus, the likelihood of individual perceptions' role could increase as a decisive factor in identifying opportunities (Simon et al. 2000), despite the fact that these perceptions were modified by personal prejudices (Baron 1998; Busenitz and Barney 1994). Baron (2004a, b) emphasized understanding the individual perception was useful and could determine why some people became entrepreneurs who are more successful than others. In this regard, Oviatt et al. (2004) considered entrepreneurs' characteristics as determinants of internationalization. Accordingly, McDougall and Oviatt (2000b) defined entrepreneurs as a mediating force in the internationalization speed, and researchers such as Gruber and MacMillan (2017) reported that entrepreneurship researchers (e.g., Powell and Baker, 2014; 2017) had analyzed the entrepreneurship phenomenon according to the identity and found that entrepreneurs make their own behavior, actions, and decisions according to their identity. In general, the entrepreneurs' personality is considered to be a multiple structure consisting of attitudes and behavior such as "proactivity," "risk taking," and "innovation" (Dess et al. 1997). In the internationalization process, entrepreneurs' interest in 
changing conditions for improvement is latent in identification of opportunities (Acedo and Jones, 2007). Kulkarni (2001) and Milliken (1990) considered the internationalization decision as a simple process with high uncertainty (Kulkarni 2001; Milliken 1990). These activities have a higher risk than those in domestic markets (Wiedersheim-Paul et al. 1978). Cavusgil and Naor (1987) found that the more companies progressed in the internationalization process, the more their risk perception was reduced (Jaffe et al. 1989; Acedo and Jones 2007) because the knowledge, which is gained in the internationalization process, affected their risk perception (Bilkey and Tesar 1977; Johanson and Wiedersheim-Paul 1975). Wally and Baum (1994) also argued that individual characteristics played key roles in the decision-making process of internationalization. Gomez-Mejia (1988) also described significant roles of individual characteristics in the risk tolerance. Acedo and Jones $(2007,236)$ found that the international orientation was along with higher proactivity and lower risk perception. They also found there was no positive relationship between the international orientation and tolerance of ambiguity. People, who had higher tolerance of ambiguity, had less risk perception and were not proactive. Instead, proactivity conditions led to less risk perception that could lead to higher internationalization speed. Barr, Stimpert, and Huff (1992) also suggested that models, which focused on individuals' mental variables, provided a better predictor of managerial strategic decisions because these psychological variables led to a better understanding of individual perceptions (Allinson et al. 2000). However, only psychological factors failed to achievement of corporate goals. This issue was neglected by Acedo and Jones (2007) who did not study roles of external factors such as employee knowledge and learning.

In the internationalization theory, Johanson and Vahlne $(1990,1997)$ found that why companies start such activities in the internationalization process? It was also stated that as businesses expanded internationally, companies would need more knowledge (e.g, for exporting unwanted products), and the knowledge acquisition from the foreign market would increase. This is not true for all cases as some researchers have stated that some companies discover opportunities that have not been perceived by others in markets during the internationalization process (Autio et al. 2000). According to the organizational learning theory, the new organizational knowledge is created in line with existing knowledge in an organization. According to Autio et al. (2000), the organizational knowledge means the ability to perceive and use relationships of critical factors that are accomplished in order to achieve desired goals. In this definition, a new knowledge, which is gained by employee, can increase by sharing knowledge among them in the organization in order to achieve specific goals (Autio et al. 2000). On the other hand, as companies have a little control over resources in international activities, they can increase their chances of success by learning (Yli-Renko et al. 2002). Therefore, it can be expected that this knowledge will lead to the achievement of specified goals in international activities, and companies with international orientation will gain more learning about markets and knowledge from their learning by increasing presence in foreign markets.

refers to tendencies and behavior that help corporate practices change in the development of resources and pursuit of new opportunities (Gupta et al. 2004). Gruber and MacMillan (2017) explained a definition by Gartner, Bird, and Starr (1992) about 
entrepreneurs' behavior as follows: "The entrepreneurial behavior refers to different behavior and activities by people during the establishment of a new organization, and they considered the Risk Perception, Proactivity and tolerance of ambiguity as dimensions of an entrepreneurial behavior". Hernandez-Perlines (2018) also studied the international orientation in family businesses. He considered three dimensions of innovation, proactivity, and risk taking for it and found a direct relationship between it with the internationalization performance of businesses. Oviatt and McDougall (2005b) also considered the entrepreneurial thinking among the first factors determining the internationalization speed mediated by the way of decision-making and perceptions of this relationship (Oviatt et al. 2004) then explained that personal characteristics such as the experience of presence in international markets and psychological traits such as risk taking made it clear how entrepreneurs behave in a business environment (Oviatt and McDougall, 2005a). Proactivity is also defined as "the company's leadership desire to advance through pursuing business opportunities" (Crant 1996). Miller and Friesen (1983) pointed out that the tendency towards the innovation makes companies more innovative, riskier, and more active than their competitors. The first hypothesis can be thus explained as follows:

Hypothesis 1 There is a significant relationship between the international orientation and proactivity.

According to the definition of tolerance of ambiguity, it is a personal characteristic by which a person can decide in uncertain risky circumstances (Westerberg et al. 1997). Sitkin and Weingart (1995) defined the tolerance of ambiguity as accepting the uncertainty as a part of work, the ability to continue a process with incomplete knowledge about the environment, and the desire to start an independent activity without a manager's knowledge about whether it will succeed (Sitkin and Weingart 1995). It can be concluded that the more entrepreneurs are willing to work in an international environment that creates more uncertainty, the more they gave the tolerance of ambiguity. Therefore, the following hypothesis is:

Hypothesis 2 There is a significant relationship between the international orientation and tolerance of ambiguity.

Entrepreneurs' ambiguity about the risk and ability to manage is associated with organizational and personal factors (Herbane, 2010; Leopoulos, 2006; Nocco and Stulz, 2006; Brustbauer, 2016). Leonidou et al. (1998) suggested that managers' psychological characteristics were associated with their perception of success or failure in international markets. Risk perception also refers to the willingness of companies to follow up projects that are not expected to have definitive outcome (Sitkin and Weingart 1995). Knight and Liesch (2002) noted the importance of collecting information and sufficient information at each stage of the internationalization process and also stated that this information led to a better understanding of managers for decision-making (Vallaster 2000). This refers to strategies, which are associated with greater risk, as well as rationality of individuals with international backgrounds (Acedo and Jones, 2007). Therefore, the following hypothesis is obtained: 
Hypothesis 3 There is a significant relationship between the international orientation and risk perception.

As mentioned, it is expected that the acquisition of knowledge and learning will be effective in international activities (Autio et al. 2000). Cohen and Levinthal (1990) argued that when companies' capacity of attraction increased, more new information was absorbed and coordinated along with business goals. This acceptance of new knowledge not only includes learning of new knowledge, but also the old knowledge (Nonaka 1994). It can be expected that international companies will be faced challenges of overcoming the existing situation and acquiring new knowledge (new experimental knowledge due to the presence in foreign markets and new organizational norms for adapting to market activities (Eriksson et al., 1997;Autio et al. 2000). Yli-Renko et al. (2002) found a significant relationship between the knowledge intensity and increased international sales. Jantunen et al. (2005) also found a significant relationship between the international orientation and international performance. The collected data from 217 newly established companies indicated that the ability to reset (new business measures, processes, models) had a significant relationship with companies' international performance. Foreign market knowledge (e.g., familiarity with language and culture of that country) is an important factor in the decision-making process associated with an international market (Johanson and Vahlne 1977). Providing a dynamic model, researchers also indicated that the amount of knowledge about a foreign market made it possible to take future decisions that were in line with resource allocation and implementation of business activities. Therefore, the following hypothesizes are obtained:

Hypothesis 4 There is a significant relationship between the international orientation and knowledge intensity.

Hypothesis 5 There is a significant relationship between the knowledge intensity and risk perception.

Hypothesis 6 There is a significant relationship between the knowledge intensity and the internationalization speed.

Tolerance of ambiguity is the ability to decide in uncertain situations (Westerberg et al. 1997). Wood and Bandura (1989) argued that relationships of individuals' personality traits and their perceptions were studied in the research literature. Therefore, it can be assumed that there is a relationship between managers' tolerance of ambiguity and their risk perception of international activities. This tolerance of ambiguity (Gupta and Govindarajan 1984) and organizational decision makers' ability to plan (Westerberg et al. 1997) make it possible for them to better deal with risk situations. Therefore, it can be considered related to the presence in international markets can help managers in processing and using the information (Acedo and Jones, 2007). Knight and Cavusgil (1996) also pointed out that managers of new international institutions have higher risk tolerance in ambiguous situations (e.g., internationalization situations); hence, the following hypothesis is obtained: 
Hypothesis 7 There is a significant relationship between the tolerance of ambiguity and risk perception.

Researchers have considered international decisions along with entrepreneurial activities leading to a relationship between their proactivity with higher international market orientation (Caughey and Chetty, 1994; Lim et al. 1996; Morgan and Katsikeas 1997). The proactivity is considered in studied by Bateman and Crant (1993), Crant (1996, 2000) and Crant and Bateman (2000) as a construct in the internationalization research as a motive for export behavior (Caughey and Chetty, 1994). Other several studies (e.g., Becherer and Maurer (1999), Entrialgo et al. (2000), Gupta and Govindarajan (1984)) found a positive relationship between the tolerance of ambiguity and entrepreneurial behavior and considered risk-taking as one of entrepreneurs' behavioral characteristics; hence, the following hypothesis is true.

Hypothesis 8 There is a significant relationship between the proactivity and risk perception.

Oviatt and McDougall (2005a) considered three dimensions for the internationalization speed including the initial speed of entry to markets, speed of market expansion in a target country, and the international commitment speed which in fact referred to the speed of foreign income growth. The entrepreneurial perception, which affects the internationalization speed, was the mediating variable of researchers' perception. According to Crant (2000), entrepreneurs' proactivity behavior enables them to study the environment in order to explore opportunities, change the situation using the initiative, and become more willing to internationalize (Andersen and Rynning 1994). Harveston et al. (2000) also stated that managers, who are more likely to think of globalization, are more risk taker. Therefore, the more the perceived risk is increased, the more the internationalization speed is negatively affected (Acedo and Jones 2007). Brustbauer (2016) found that companies with proactive perspective in their risk management expanded their market and products. Beasley et al. (2005) and Liebenberg and Hoyt (2003) indicated that the risk often led to opportunities. Therefore, the following hypothesis was true:

Hypothesis 9 There is a significant relationship between the risk perception and internationalization speed.

Figure 1 presents the research model. It is the expanded model of Acedo and Jones (2007). Given that different studies such as those by Yli-Renko et al. (2002) and Autio et al. (2000) emphasized the importance of knowledge intensity in international activities, this model investigated relationships of international orientation, knowledge intensity, risk perception, and internationalization speed.

\section{Research methodology}

The present study was applied in terms of objective and descriptive-survey according to data collection and analysis. This research was descriptive because it described the status of variables as well as their relationships. It was also survey because it analyzed comments by respondents (studied sample), who responded to questions about the research subject and dimensions (variables and related questions), using a questionnaire. 


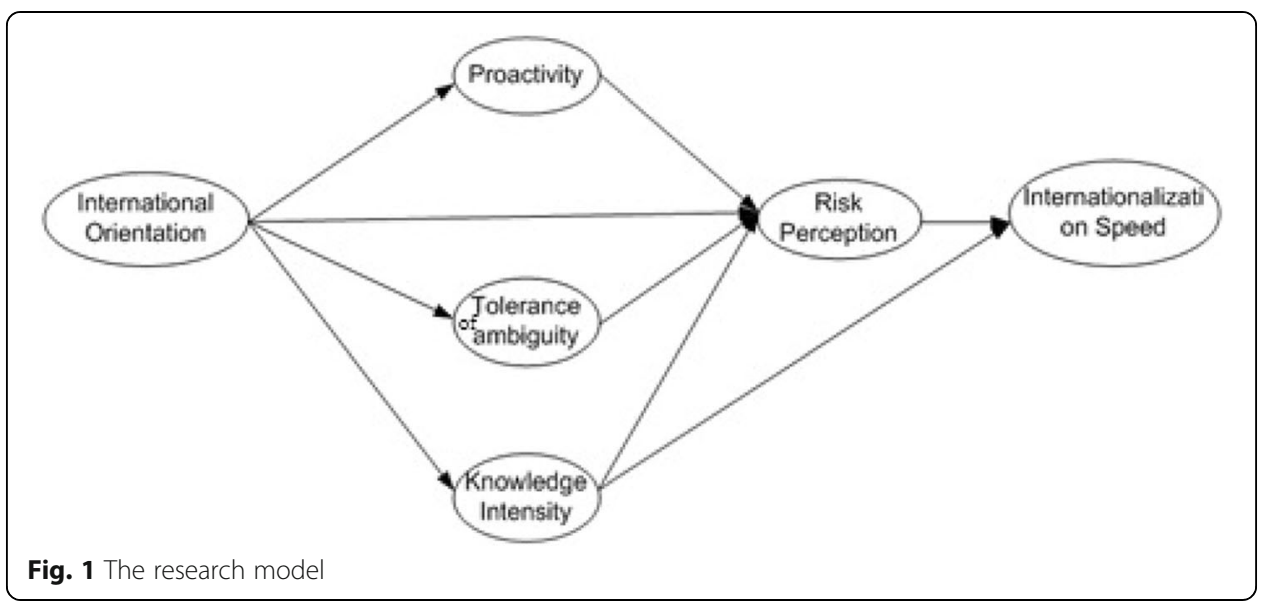

In the present research, an individual is the unit of analysis; and the statistical population consisted of all owners of small and medium-sized enterprises in Tous industrial estates located in Mashhad, Iran. Most industries are located in cities industrial units of three phases of this estate. It should be noted selected industries of the present research were private and non-state-owned and not affiliated to government and any public enterprises, and thus, the present research considered the industry owners who set up a business unit. According to the definition of the Ministry of Industry, Mine and Trade (2018), units with 1 to 49 employees are put in the group of small industries, 50 to 99 employees are considered to be medium-sized, and 100 employees and over are put in the large industrial group. Since the present research focused on companies active in the international market and based on the obtained information from industrial estates of Khorasan Razavi province, a total of 202 international companies were active among which 93 were large, 67 medium, and 42 were small companies. The studied population consisted of CEOs, board of directors, and marketing and sales managers from 109 companies in the group of small and medium enterprises. A simple random sampling method was used to distribute questionnaires. 450 questionnaires were distributed among members of the statistical population, since Roscoe (1975) considered an

Table 1 Results of demographic data

\begin{tabular}{|c|c|c|c|}
\hline Variable & Domain & No. & Percentage \\
\hline \multirow[t]{2}{*}{ Gender } & Male & 279 & 87.2 \\
\hline & Female & 41 & 12.8 \\
\hline \multirow[t]{2}{*}{ Marital status } & Married & 290 & 90.7 \\
\hline & Single & 30 & 9.3 \\
\hline \multirow[t]{4}{*}{ Education level } & High school diploma and associate degree & 48 & 15 \\
\hline & Bachelor & 139 & 43.5 \\
\hline & Master & 89 & 27.8 \\
\hline & $\mathrm{PhD}$ & 44 & 13.7 \\
\hline \multirow[t]{4}{*}{ Work experience } & Less than 5 years & 93 & 29.1 \\
\hline & From 6 to 10 years & 76 & 23.7 \\
\hline & From 11 to 15 years & 89 & 27.8 \\
\hline & More than 16 years & 62 & 19.4 \\
\hline Total & & 320 & 100 \\
\hline
\end{tabular}


appropriate sample size of 300 to 500 correct questionnaires for the analysis. Among them, 343 questionnaires returned; 23 ones had incomplete information and were excluded, and 320 questionnaires were analyzed.

Questions of the questionnaire were extracted from previous papers. The questionnaire of this research consisted of two parts; the first part contained demographic questions including gender, marital status, work experience, and education level. Table 1 presents results of demographic information. The second part contained specialized questions for measuring variables including 27 questions, and answers of questionnaire were degreed on a 5-point Likert scale from completely disagree (1), disagree (2), neither agree nor disagree (3), agree (4), and completely agree (5) by which respondents could determine their degree of approval on a Likert scale ranging from one to five. Previous research questions were used to measure variables. The international orientation, proactivity, tolerance of ambiguity, risk perception, and internationalization speed are extracted from the Acedo and Jones's questionnaire (2007). The present papers also extracted questions from previous research. The knowledge intensity was also measured using questions of a questionnaire by Autio et al. (2000) including a total of 27 questions.

\section{Results}

As shown in Table 1, from 320 subjects, 279 males (87.2\%) and 41 females (12.8\%) participated in the present research. In terms of the marital status, 290 (90.7\%) were married, and 30 were single (9.3\%). In terms of education level, 48 (15\%) subjects had high school diplomas and associate degrees, 139 (43.5\%) had bachelor degrees, 89 subjects (27.8\%) had master's degrees, and 44 subjects (13.7\%) had doctoral degrees. In terms of work experience, 93 subjects $(29.1 \%)$ had less than 5 years of work experience, 76 (23.7\%) had 6-10 years of work experience, $89(27.8 \%)$ had 11 to 15 years of work experience, and 62 subjects $(19.4 \%)$ had over 16 years of work experience. Also, in Table 1, results of demographic data is shown.

In the present research, SPSS22, Lisrel, and Smart PLS software were used to analyze data. Structural equation modeling (SEM) is used to test hypotheses and the model fit. SEM is an overall powerful technique from a multivariate regression family; in other words, it allows the expansion of a general linear model and simultaneously examines a set of regression equations. This model is a comprehensive approach for testing hypotheses about relationships of observed and latent variables.

Table 2 Average variance extracted and reliability of questionnaire components

\begin{tabular}{lllll}
\hline Variable & & Cronbach's alpha & Composite reliability & AVE \\
\hline International orientation & IO & 0.8834 & 0.9198 & 0.7418 \\
Proactivity & PR & 0.9497 & 0.9568 & 0.6895 \\
Tolerance of ambiguity & TA & 0.8897 & 0.9237 & 0.7517 \\
Knowledge intensity & KI & 0.8666 & 0.9183 & 0.7894 \\
Risk rerception & RP & 0.9116 & 0.9379 & 0.7906 \\
Internationalization speed & IS & 0.8834 & 0.9507 & 0.9061 \\
\hline
\end{tabular}




\section{Reliability and validity of the measurement tool}

The internal validity was studied in order to determine the reliability of applied tool. The internal validity assessment is a widely-used method for assessing the reliability of measurement models. The internal validity analysis follows the proposed method for comparing three indices of consistency (composite reliability, Cronbach's alpha, and average variance extracted (AVE) with a critical value) (Bagozzi et al. 1991). Table 2 presents coefficients of internal validity indices. All composite reliability coefficients are higher than the critical value (0.7) (Nonally 1978), and all Cronbach's alpha coefficients are more than 0.5 . Therefore, it can be concluded that the reliability of measurement models is acceptable.

Measurement of the measurement tool validity was also carried out through convergent and divergent validity. Validity measurement refers to an assessment of the ability of measurement models to measure a target phenomenon. The examination of construct validity through evaluation of divergent and convergent validity of measurement models is a powerful method in this regard. According to Fornell-Larcker criterion (1981) for convergent validity, the AVE should be higher than 0.5. In other words, a latent variable can, on average, account for more than a half of dispersion of its reagents. Table 2 presents calculated values for research variables. Values of the average variance extracted indicate the convergent validity of main research variables. Divergent validity (differential) is a complementary concept and covers two criteria in PLS path modeling: Fornell-Larcker criterion and transverse load test. Fornell-Larcker criterion indicates that a variable should have a greater dispersion among its reagents than reagents of other variables. The AVE of each variable should be statistically greater than the maximum square root of correlation between that variable with other variables. Fornell-Larcker criterion evaluates the differential validity in a construct. This criterion indicates that to ensure differential (divergent) validity, the AVE of each variable should be greater than the square root of correlation between that variable with other variables, or in other words, the AVE squared should be less than the correlation of variables. The divergent validity of research variables is confirmed according to results of Table 2. Results indicate the acceptable reliability and validity of measurement tool (questionnaire). In the next section, research hypotheses are examined using the structural equation model.

Results of confirmatory factor analysis of all research variables indicate that all measurement models are suitable; and all values and parameters of model are significant (Table 3). In Table 2, AVE values, which are all higher than 0.5, and the composite reliability (which are all higher than 0.7 ) indicate that the measurement model of all research variables has a good fit; and the convergent validity of indices for main research variables is relatively high. The structural equation modeling in Fig. 2 LISREL software (path analysis) was used to test hypotheses.

\section{Correlation analysis and differential validity of research variables in a general model}

According to results of Table 4, there is a mutual positive and significant relationship between all research variables. AVE values indicate the convergence validity of main research variables. The divergent validity of variables is also confirmed. The squared AVE of each latent variable should be statistically more than the highest correlation of that variable with other variables. 
Table 3 Standardized coefficients, $T$ values of research questions

\begin{tabular}{|c|c|c|c|}
\hline Variable & Item & Standardized coefficient & $T$ values \\
\hline \multirow[t]{4}{*}{ International orientation } & 101 & 0.82 & 17.26 \\
\hline & 102 & 0.86 & 18.52 \\
\hline & 103 & 0.85 & 18.03 \\
\hline & 104 & 0.71 & 13.91 \\
\hline \multirow[t]{10}{*}{ Proactivity } & PR1 & 0.72 & 14.6 \\
\hline & PR2 & 0.82 & 17.64 \\
\hline & PR3 & 0.84 & 18.51 \\
\hline & PR4 & $0 . .86$ & 18.99 \\
\hline & PR5 & 0.79 & 16.91 \\
\hline & PR6 & 0.73 & 14.99 \\
\hline & PR7 & 0.84 & 18.3 \\
\hline & PR8 & 0.87 & 19.51 \\
\hline & PR9 & 0.86 & 19.13 \\
\hline & PR10 & 0.75 & 15.69 \\
\hline \multirow[t]{4}{*}{ Tolerance of ambiguity } & TA1 & 0.81 & 16.95 \\
\hline & TA2 & 0.86 & 18.43 \\
\hline & TA3 & 0.77 & 15.72 \\
\hline & TA4 & 0.84 & 17.98 \\
\hline \multirow[t]{3}{*}{ Knowledge intensity } & KN1 & 0.84 & 17.85 \\
\hline & KN2 & 0.85 & 18.19 \\
\hline & KN3 & 0.79 & 16.23 \\
\hline \multirow[t]{4}{*}{ Risk perception } & RP1 & 0.84 & 18.16 \\
\hline & $\mathrm{RP} 2$ & 0.89 & 19.84 \\
\hline & RP3 & 0.85 & 18.29 \\
\hline & $\mathrm{RP} 4$ & 0.83 & 17.47 \\
\hline \multirow[t]{2}{*}{ Internationalization speed } & IS1 & 0.91 & 19.7 \\
\hline & 152 & 0.89 & 18.87 \\
\hline
\end{tabular}

Investigating research hypotheses (structural equation model)

Evaluation of fit indices of model

Before the hypothesis testing by the model, eight common indices along with an acceptable value of each suggested index in the past research were used to examine the fit of conceptual model (Hair et al. 1998). Fit indices indicate the competency of conceptual model of research in measuring the research population, or in other words, they indicate to what extent the collected data supports the research model. It should be noted that there are different parameters affecting these indices, for instance, some of them are strongly sensitive to the sample size. Therefore, all indices should be considered for investigating the model fit; and low indices of model fit in one or more indexes do not mean that the model is not fit. According to the Table 5, it the conceptual model of research has a good fit with the collected data.

\section{Structural equation modeling (structural research model)}

Direct influence is a type of relationships between latent variables in a structural equation model. It is in fact a component of structural equation model and shows a directed 


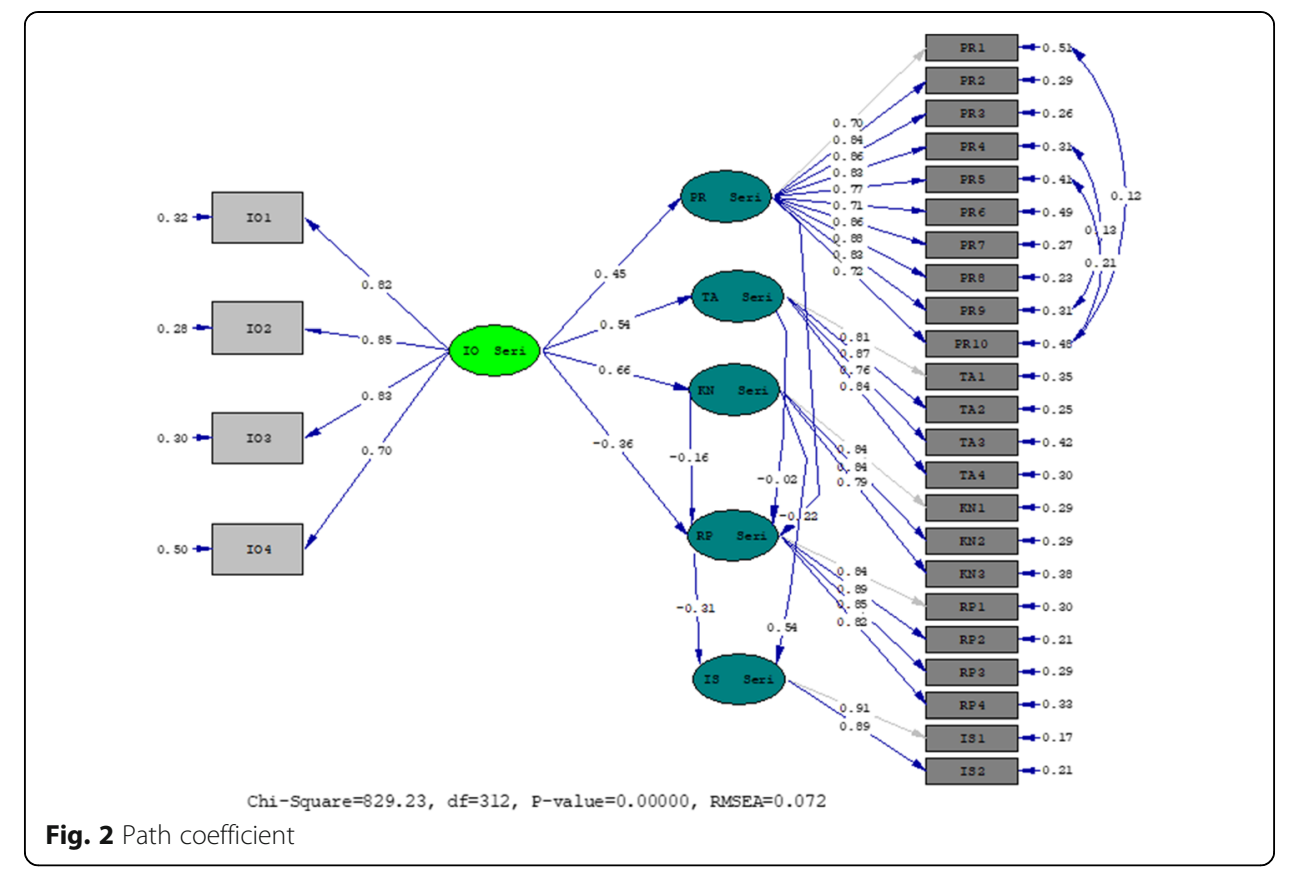

relationship between two variables. This type of influence represents an assumed linear causal effect of a variable on another variable. In a model, each direct influence indicates a relationship between a dependent and an independent variable; however, a dependent variable in another direct influence can be an independent variable, and vice versa. The structural model examines relationships between exogenous and endogenous latent variables. In the following model, the international orientation (IO) is exogenous and independent latent variable. The tolerance of ambiguity (TA), proactivity (PR), knowledge intensity (KI), and risk perception (RP) are endogenous and meditative latent variables, but the internationalization speed (IS) is endogenous and dependent latent variables.

Table 4 Pearson correlation

\begin{tabular}{|c|c|c|c|c|c|c|c|}
\hline & & 10 & $P R$ & TA & $\mathrm{KI}$ & $\mathrm{RP}$ & IS \\
\hline \multirow[t]{2}{*}{10} & Correlation & 0.8612 & & & & & \\
\hline & Significance & & & & & & \\
\hline \multirow[t]{2}{*}{$P R$} & Correlation & 0.335 & 0.8303 & & & & \\
\hline & Significance & 0.000 & & & & & \\
\hline \multirow[t]{2}{*}{ TA } & Correlation & 0.435 & 0.422 & 0.867 & & & \\
\hline & Significance & 0.000 & 0.000 & & & & \\
\hline \multirow[t]{2}{*}{$\mathrm{Kl}$} & Correlation & 0.514 & 0.504 & 0.595 & 0.8884 & & \\
\hline & Significance & 0.000 & 0.000 & 0.000 & & & \\
\hline \multirow[t]{2}{*}{ RP } & Correlation & -0.489 & -0.303 & -0.377 & -0.485 & 0.8891 & \\
\hline & Significance & 0.000 & 0.000 & 0.000 & 0.000 & & \\
\hline \multirow[t]{2}{*}{ IS } & Correlation & 0.567 & 0.372 & 0.51 & 0.598 & -0.517 & 0.9518 \\
\hline & Significance & 0.000 & 0.000 & 0.000 & 0.000 & 0.000 & \\
\hline
\end{tabular}

** Significant at the error level of $0.01 \%$ 
Table 5 Fit indices of model

\begin{tabular}{llll}
\hline Reliable value & Model statistics & Fit index & Utility \\
\hline$<5$ & 657.2 & $\mathrm{X} 2 / \mathrm{df}$ & Confirmed model \\
$<0.08$ (Joreskong and Sorbom, 1996) & 0.072 & RMSEA $^{\mathrm{a}}$ & Confirmed model \\
$>0.80$ (Fornell and Larcker, 1981) & 0.96 & $\mathrm{NFl}^{\mathrm{b}}$ & Confirmed model \\
$>0.80$ (Bagozzi and Yi, 1988 & 0.96 & $\mathrm{NNFl}^{\mathrm{c}}$ & Confirmed model \\
$>0.80$ (Joreskong and Sorbom, 1996) & 0.97 & $\mathrm{CFI}^{\mathrm{d}}$ & Confirmed model \\
$>0.80$ (Bagozzi and Yi, 1988) & 0.85 & $\mathrm{GFl}^{\mathrm{e}}$ & Confirmed model \\
$>0.80$ (Etezadi-Amoli and Farhoomand, 1996) & 0.80 & $\mathrm{AGFl}^{\mathrm{f}}$ & Confirmed model \\
\hline
\end{tabular}

${ }^{\mathrm{a}}$ Root mean square error of approximation

${ }^{b}$ Normed fit index

${ }^{\mathrm{c}}$ Non-normed fit index

${ }^{\mathrm{d}}$ Comparative fit index

${ }^{\mathrm{e}}$ Goodness of fit index

${ }^{\mathrm{f}}$ Adjusted Goodness of fit index

In general, the significance value can be determined based on critical values of 1.96 and -1.96 . To this end, a significant relationship is confirmed if a significance Fig. 3 coefficient is greater than 1.96 or less than -1.96 (Esposito-Vinzi et al. 2010, p. 68). Sobel test was used to examine the mediating role of variables. Table 6 presents results of hypotheses in LISREL software.

\section{Conclusion}

As mentioned, the present paper aimed to investigate relationships of managers' entrepreneurial perceptions and the internationalization speed in small and medium-sized enterprises. To this end, the research questionnaires were distributed in international private manufacturing companies in an industrial estate of Khorasan Razavi province in Iran. A theoretical model by Acedo and Jones (2007) was used to investigate relationships of managers and entrepreneurs' perceptions with internationalization speed of companies. Given that other studies considered the amount of knowledge as a determinant of internationalization speed, this variable was added to target model and a more comprehensive model was examined. The obtained result of the first hypothesis indicated that there was a significant relationship between the international orientation and proactivity, but there was no significant relationship between them in a research by Acedo and Jones (2007). Two points were important in a definition by Crant (1996), the proactive people were more inclined to be proactive; and they followed business opportunities, both of which were consistent with personality characteristics of entrepreneurs (Gupta et al. 2004; Gartner et al. 1992) who were willing to supply their products at international levels. Given the positive relationship, the more the international orientation increases, the more the entrepreneurs' proactivity is enhanced, and they are increasingly looking for business opportunities. The second hypothesis confirmed that there was a significant relationship between the international orientation and tolerance of ambiguity; and this result was consistent with results of research by Acedo and Jones (2007). Given the positive relationship, it can be concluded that the more the entrepreneurs' willingness increases to supply their products and services at international levels, the more their tolerance of ambiguity and decision-making increase in ambiguous conditions. It was consistent with defined characteristics by researchers such as Westerberg et al. 1997; Sitkin and Weingart 1995). In the third hypothesis, a significant relationship 


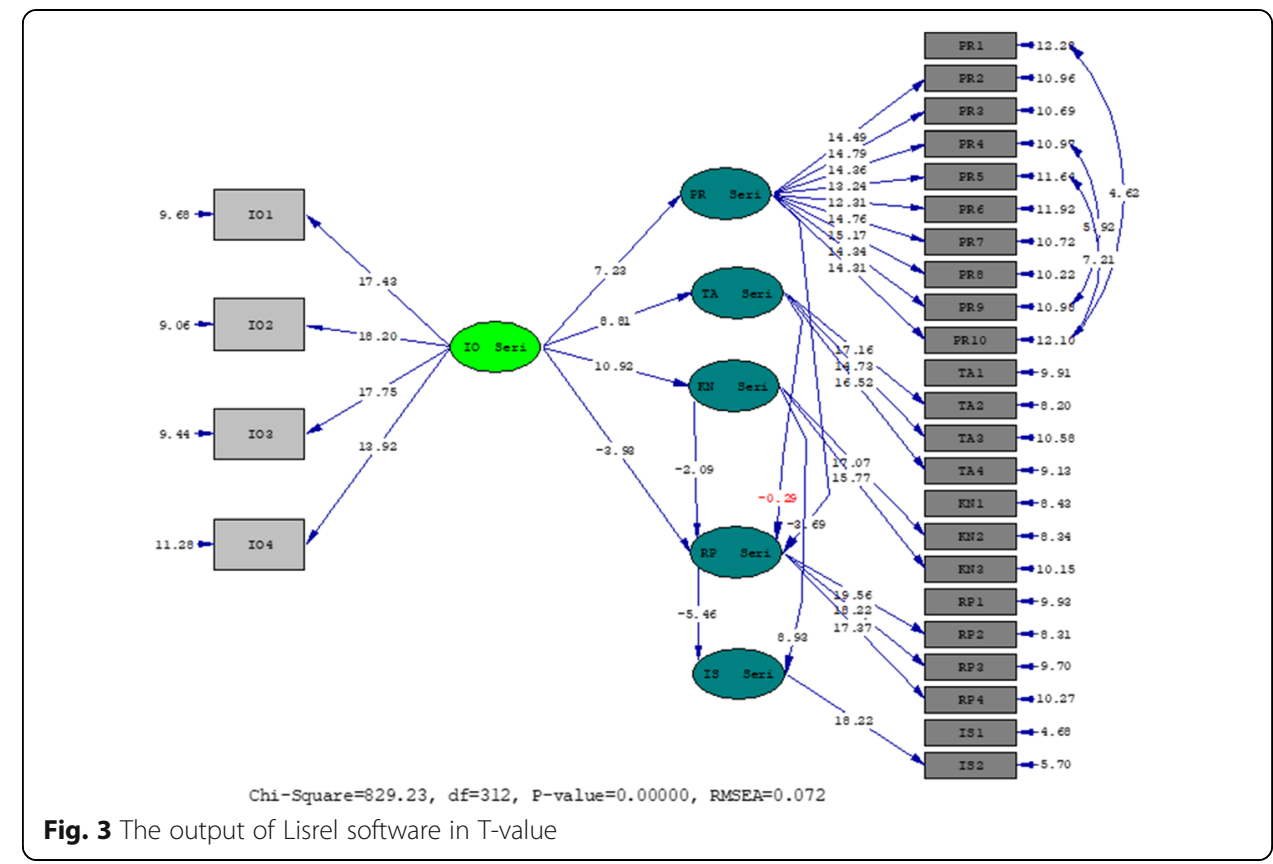

was found between the international orientation and risk perception, and it was a negative relationship. This result was consistent with results of research by Acedo and Jones (2007). It can be concluded that the more the entrepreneurs' international orientation increases, the more their risk perceptions are reduced and entrepreneurs tend to invest internationally in projects with reasonable risks in spite of their risk taking compared with other individuals (Sitkin and Weingart 1995) in order to reduce their risk of failure. The fourth hypothesis confirmed a significant relationship between the international orientation and knowledge intensity. According to their positive relationship, the more the entrepreneurs' international orientation increases, the more the knowledge intensity increases. International companies achieve the higher learning and knowledge and adapt themselves to existing situations over time. Johanson and Vahlne $(1990,1997)$ argued that as internationalization measures expand, they need to be more knowledgeable. The fifth hypothesis confirmed that there was a negative relationship between the knowledge intensity and risk perception. Jantunen et al. (2005) found that along with increased international activities, companies knew about the culture and languages of other countries and utilized new processes, measures, and models of business to work in international markets. On the other hand, the risk perception was defined as the entrepreneurs' willingness to pursue projects with not sufficient certainty; hence, it can be argued that the more the level of knowledge increases, the more the entrepreneurs' risk perception is reduced, and thus, there is a negative relationship between these two variables. It was also confirmed that there was a positive relationship between the knowledge intensity and internationalization speed. Therefore, it can be concluded that the more the level of learning and knowledge of active enterprises in the international market increases, the more their speed of internationalization and entry into international markets increases. Yli-Renko et al. (2002) found that international companies increased their success through learning and thus achieve their goals by supplying their products faster than their rivals. The eighth hypothesis found 
Table 6 Relationships of LISREL software

\begin{tabular}{|c|c|c|c|c|}
\hline & $\begin{array}{l}\text { Standardized } \\
\text { coefficient }\end{array}$ & Significance & Effect & Result \\
\hline $\begin{array}{l}\text { There is a significant relationship between } \\
\text { the international orientation and proactivity }\end{array}$ & 0.45 & 7.33 & Direct & Confirmed \\
\hline $\begin{array}{l}\text { There is a significant relationship between } \\
\text { the international orientation and tolerance } \\
\text { of ambiguity }\end{array}$ & 0.54 & 8.81 & Direct & Confirmed \\
\hline $\begin{array}{l}\text { There is a significant relationship between the } \\
\text { international orientation and risk perception }\end{array}$ & -0.36 & -3.93 & Direct & Confirmed \\
\hline $\begin{array}{l}\text { There is a significant relationship between the } \\
\text { international orientation and knowledge intensity }\end{array}$ & 0.66 & 10.92 & Direct & Confirmed \\
\hline $\begin{array}{l}\text { There is a significant relationship between the } \\
\text { knowledge intensity and risk perception }\end{array}$ & -0.16 & -2.09 & Direct & Confirmed \\
\hline $\begin{array}{l}\text { There is a significant relationship between } \\
\text { the knowledge intensity and internationalization } \\
\text { speed }\end{array}$ & 0.54 & 8.93 & Direct & Confirmed \\
\hline $\begin{array}{l}\text { There is a significant relationship between } \\
\text { the tolerance of ambiguity and risk perception }\end{array}$ & -0.02 & -0.29 & Direct & Rejected \\
\hline $\begin{array}{l}\text { There is a significant relationship between the } \\
\text { proactivity and risk perception }\end{array}$ & -0.22 & -3.69 & Direct & Confirmed \\
\hline $\begin{array}{l}\text { There is a significant relationship between the } \\
\text { risk perception and internationalization speed }\end{array}$ & -0.31 & -5.46 & Direct & Confirmed \\
\hline $\begin{array}{l}\text { Proactivity has a mediating role in the relationship } \\
\text { between the international orientation and risk } \\
\text { perception. }\end{array}$ & $0.45 \times 0.22=0.099$ & -4.569 & Indirect & Confirmed \\
\hline $\begin{array}{l}\text { Tolerance of ambiguity has a mediating role in } \\
\text { the relationship between the international } \\
\text { orientation and risk perception. }\end{array}$ & $0.54 \times-0.02=-0.01$ & -0.0498 & Indirect & Rejected \\
\hline $\begin{array}{l}\text { Risk perception has a mediating role in the } \\
\text { relationship between the international } \\
\text { orientation and internationalization speed. }\end{array}$ & $-0.36 \times-0.031=0.1116$ & 5.678 & Indirect & Confirmed \\
\hline $\begin{array}{l}\text { Knowledge intensity has a mediating role in the } \\
\text { relationship between the international orientation } \\
\text { and internationalization speed. }\end{array}$ & $0.66 \times 0.54=0.3564$ & 945.1 & Indirect & Confirmed \\
\hline
\end{tabular}

that there was a significant negative relationship between proactivity and risk perception, and it was consistent with result of a research by Acedo and Jones (2007). Other researchers (such as Miller and Friesen 1983) also considered the proactivity as a constituent of entrepreneurship orientation. It can be concluded that the more entrepreneurs are looking for opportunities in international markets, the more they are looking for less risk perception. Given that international entrepreneurial managers should be decision makers, they seek to utilize market opportunities that increase their proactivity; and these measures motivate their export behavior (Caughey and Chetty, 1994). The ninth hypothesis also found a negative relationship between the risk perception and internationalization speed; and it was consistent with a research by Acedo and Jones (2007). It can be concluded that the more the entrepreneurs' risk perception increases, the more their presence in international markets is reduces and they try to collect information and acquire knowledge in order to reduce risk and enter international markets with higher knowledge. Hypotheses, which examined mediating effects of proactivity, risk perception, tolerance of ambiguity, and the knowledge intensity, confirmed that the proactivity, risk perception, and knowledge intensity had mediating effects. 
According to the results in this research, some recommendations are suggested to SMEs which supply their products to other countries:

It is recommended to MSEs that export their products to other countries to employ managers who have international mind and positive attitude in international markets. These managers have high tolerance ambiguity from the situation and productivity and can do risk. So according to competitive environment in global markets, they can supply their products and services in optimal speed. On the other hand, since international market's environments differ from interior markets, for reducing risk perception, adequate data should be collected. In addition of risk perception, increasing internationalization speed and if their activity in international target markets decrease, the amount of their knowledge increase. So in consequence, ambiguity and risk will be completed to large companies, and their internationalization speed will increase far more.

The present research sought to develop a model and study relationships of variables beyond psychological elements. Therefore, the knowledge level was added to Acedo and Jones's model (2007). It is suggested examining the mentioned model in other countries according to the proposed new model in order to achieve a more comprehensive perspective. Researchers are also suggested conducting future research on separate industry in order to investigate the impact of each industry on relationships of variables. Also, it is recommended that the model is further tested using a larger sample size from diverse cultural settings.

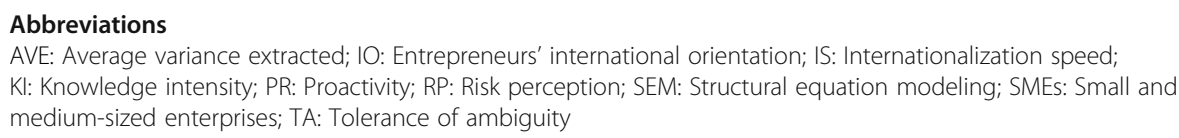

The datasets used and analyzed during the current study are available from the corresponding author on reasonable request.

\section{Authors' contributions}

SS analyzed the data collected for the study and prepared the manuscript while AA edited the draft and provided technical support in mentoring SS. MM revised the literature review section and TH provided technical support in the "Research methodology" section. Also, all the authors read and approved the final manuscript.

Competing interests

We declare that they have no competing interests.

\section{Publisher's Note}

Springer Nature remains neutral with regard to jurisdictional claims in published maps and institutional affiliations.

\section{Author details}

${ }^{1}$ Islamic Azad University of Neyshabour, Neyshabour, Iran. ${ }^{2}$ Lorestan State University, Khorramabad, Iran. ${ }^{3}$ Tehran, Iran.

${ }^{4}$ Ferdowsi University, Mashhad, Iran.

Received: 11 October 2018 Accepted: 29 January 2019

Published online: 04 March 2019

References

Acedo, F. J., \& Jones, M. V. (2007). Speed of internationalization and entrepreneurial cognition: Insights and a comparison between international new ventures, exporters and domestic firms. Journal of World Business, 42(3), $236-252$. 
Allinson, C. W., Chell, E., \& Hayes, J. (2000). Intuition and entrepreneurial behaviour. European Journal of Work and Organizational Psychology, 9(1), 31-43.

Andersen, O., \& Rynning, M. R. (1994). Prediction of export intentions-managing with structural characteristics? Scandinavian Journal of Management, 10(1), 17-27.

Autio, E., Sapienza, H. J., \& Almeida, J. G. (2000). Effects of age at entry, Knowledge Intensity, and imitability on international growth. Academy of Management Journal, 43(5), 909-924.

Bagozzi, R. P., \& Yi, Y. (1988). On the evaluation of structural equation models. Journal of the Academy of Marketing Science, 16(1), 74-94.

Bagozzi, R. P., Yi, Y., \& Phillips, L. W. (1991). Assessing construct validity in organizational research. Administrative Science Quarterly, 36, 421-458.

Baron, R. A. (1998). Cognitive mechanisms in entrepreneurship: Why and when enterpreneurs think differently than other people. Journal of Business Venturing, 13(4), 275-294

Baron, R. A. (2004a). The cognitive perspective: a valuable tool for answering entrepreneurship's basic "why" questions. Journal of Business Venturing, 19(2), 221-239.

Baron, R. A. (2004b). Potential benefits of the cognitive perspective: expanding entrepreneurship's array of conceptual tools.

Baron, R. A., \& Ward, T. B. (2004). Expanding entrepreneurial cognition's toolbox: Potential contributions from the field of cognitive science. Entrepreneurship Theory and Practice, 28(6), 553-573.

Barr, P. S., Stimpert, J. L., \& Huff, A. S. (1992). Cognitive change, strategic action, and organizational renewal. Strategic Management Journal, 13(S1), 15-36.

Bateman, T. S., \& Crant, J. M. (1993). The proactive component of organizational behavior: A measure and correlates. Journal of Organizational Behavior, 14(2), 103-118.

Beasley, M. S., Clune, R., \& Hermanson, D. R. (2005). Enterprise risk management: An empirical analysis of factors associated with the extent of implementation. Journal of Accounting and Public Policy, 24(6), 521-531.

Becherer, R. C., \& Maurer, J. G. (1999). The proactive personality disposition and entrepreneurial behavior among small company presidents. Journal of Small Business Management, 37(1), 28.

Bhuian, S. N., Menguc, B., \& Bell, S. J. (2005). Just entrepreneurial enough: the moderating effect of entrepreneurship on the relationship between market orientation and performance. Journal of Business Research, 58(1), 9-17.

Bilkey, W. J., \& Tesar, G. (1977). The export behavior of smaller-sized Wisconsin manufacturing firms. Journal of International Business Studies, 8(1), 93-98.

Brustbauer, J. (2016). Enterprise risk management in SMEs: Towards a structural model. International Small Business Journal, 34(1), 70-85.

Busenitz, L. W., \& Barney, J. B. (1994). Biases and heuristics in strategic decision making: Differences between entrepreneurs and managers in large organizations. Academy of Management Proceedings. 1994:1;85-89). Briarcliff Manor: Academy of Management.

Business Week. (1992). Little companies, big exports (Vol. 13, pp. 70-72).

Caughey, M., \& Chetty, S. (1994). Pre-export behaviour of small manufacturing firms in New Zealand. International Small Business Journal, 12(3), 62-68.

Cavusgil, S. T., \& Knight, G. (2015). The born global firm: An entrepreneurial and capabilities perspective on early and rapid internationalization. Journal of International Business Studies, 46(1), 3-16.

Cavusgil, S. T., \& Naor, J. (1987). Firm and management characteristics as discriminators of export marketing activity. Journal of Business Research, 15(3), 221-235.

Cavusgil, S. T., \& Nevin, J. R. (1981). Internal determinants of export marketing behavior: An empirical investigation. Journal of Marketing Research, 18, 114-119.

Chen, H. L., \& Huang, Y. (2004). The establishment of global marketing strategic alliances by small and medium enterprises. Small Business Economics, 22(5), 365-377.

Cohen, W. M., \& Levinthal, D. A. (1990). Absorptive capacity: A new perspective on learning and innovation. Administrative Science Quarterly, 35, 128-152.

Crant, J. M. (1996). The proactive personality scale as a predictor of entrepreneurial intentions. Journal of Small Business Management, 34, 42-49

Crant, J. M. (2000). Proactive behavior in organizations. Journal of Management, 26(3), 435-462.

Crant, J. M., \& Bateman, T. S. (2000). Charismatic leadership viewed from above: The impact of proactive personality. Journal of Organizational Behavior, 21(1), 63-75.

Dess, G. G., Lumpkin, G. T., \& Covin, J. G. (1997). Entrepreneurial strategy making and firm performance: Tests of contingency and configurational models. Strategic Management Journal, 18(9), 677-695.

Eisenhardt, K. M., \& Schoonhoven, C. B. (1990). Organizational growth: Linking founding team, strategy, environment, and growth among US semiconductor ventures, 1978-1988. Administrative Science Quarterly, 504-529.

Ely, R. T., \& Hess, R. H. (1893). Outline of Economics. New York: Macmillan.

Entrialgo, M., Fernández, E., \& Vázquez, C. J. (2000). Psychological characteristics and process: the role of entrepreneurship in Spanish SMEs. European Journal of Innovation Management, 3(3), 137-149.

Esposito-Vinzi, V., Wynne, W., Chin, W. W., Henseler, J., \& Wang, H. (Eds.). (2010). Handbook of Partial Least Squares: Concepts, Methods and Applications. New York: Springer Verlag.

Etemad, H., \& Wright, R. W. (Eds.). (2003). Globalization and entrepreneurship: policy and strategy perspectives. Edward Elgar Publishing.

Etezadi-Amoli, J., \& Farhoomand, A. F. (1996). A structural model of end user computing satisfaction and user performance. Information \& Management, 30(2), 65-73.

Fornell, C., \& Larcker, D. F. (1981). Structural equation models with unobservable variables and measurement error: Algebra and statistics. Journal of Marketing Research, 382-388.

Gartner, W. B., Bird, B. J., \& Starr, J. A. (1992). Acting as if: Differentiating entrepreneurial from organizational behavior. Entrepreneurship Theory and Practice, 16(3), 13-32. 
Gomez-Mejia, L. R. (1988). The role of human resources strategy in export performance: A longitudinal study. Strategic Management Journal, 9(5), 493-505.

Gruber, M., \& MacMillan, I. C. (2017). Entrepreneurial behavior: A reconceptualization and extension based on identity theory. Strategic Entrepreneurship Journal, 11(3), 271-286.

Gupta, A. K., \& Govindarajan, V. (1984). Business unit strategy, managerial characteristics, and business unit effectiveness at strategy implementation. Academy of Management Journal, 27(1), 25-41.

Gupta, V., MacMillan, I. C., \& Surie, G. (2004). Entrepreneurial leadership: developing and measuring a cross-cultural construct. Journal of Business Venturing, 19(2), 241-260.

Gürol, Y., \& Atsan, N. (2006). Entrepreneurial characteristics amongst university students: Some insights for entrepreneurship education and training in Turkey. Education and Training, 48(1), 25-38.

Hair, J. F., Anderson, R. E., Tatham, R. L., \& Black, W. C. (1998). Multivariate Data Analysis (pp. 7-232). Upper Saddle River: Prentice-Hall.

Harveston, P. D., Kedia, B. L., \& Davis, P. S. (2000). Internationalization of born global and gradual globalizing firms: The impact of the manager. Journal of Competitiveness Studies, 8(1), 92.

Hernandez-Perlines, F. (2018). Moderating effect of absorptive capacity on the entrepreneurial orientation of international performance of family businesses. Journal of Family Business Management, 8(1), 58-74.

Jaffe, E. D., Nebenzahl, I. D., \& Pasternak, H. (1989). The export behavior of small and medium-sized Israeli manufacturers. Journal of Global Marketing, 2(2), 27-51.

Jantunen, A., Puumalainen, K., Saarenketo, S., \& Kyläheiko, K. (2005). Entrepreneurial orientation, dynamic capabilities and international performance. Journal of International Entrepreneurship, 3(3), 223-243.

Johanson, J., \& Vahlne, J. E. (1977). The internationalization process of the firm-a model of knowledge development and increasing foreign market commitments. Journal of International Business Studies, 8(1), 23-32.

Johanson, J., \& Vahlne, J. E. (1990). The mechanism of internationalisation. International Marketing Review, 7(4).

Johanson, J., \& Wiedersheim-Paul, F. (1975). The internationalization of the firm—four swedish cases 1. Journal of Management Studies, 12(3), 305-323.

Joreskog, K. G., \& Sorbom, D. (1996). LISREL 8 user's reference guide. Uppsala: Scientific Software International.

Knight, G., \& Cavusgil, S. T. (1996). The born global firm: A challenge to traditional internationalization theory. In C. R. Taylor (Ed.), Advances of international marketing (pp. 11-26). New York: JAl Press.

Knight, G. A., \& Liesch, P. W. (2002). Information internalisation in internationalising the firm. Journal of Business Research, 55(12), 981-995.

Krueger, N. F. (2003). The cognitive psychology of entrepreneurship. In Handbook of entrepreneurship research (pp. 105-140). Boston: Springer.

Kula, V., \& Tatoglu, E. (2003). An exploratory study of Internet adoption by SMEs in an emerging market economy. European Business Review, 15(5), 324-333.

Kulkarni, S. P. (2001). The influence of the type of uncertainty on the mode of international entry. American Business Review, 19(1), 94.

Leonidou, L. C., Katsikeas, C. S., \& Piercy, N. F. (1998). Identifying managerial influences on exporting: past research and future directions. Journal of International Marketing, 6, 74-102.

Liebenberg, A. P., \& Hoyt, R. E. (2003). The determinants of enterprise risk management: Evidence from the appointment of chief risk officers. Risk Management and Insurance Review, 6(1), 37-52.

Lim, J. S., Sharkey, T. W., \& Kim, K. I. (1996). Competitive environmental scanning and export involvement: an initial inquiry. International Marketing Review, 13(1), 65-80.

Matviuk, S. G. (2010). A Study of Peruvian Entrepreneurs Leadership Expectations. Journal of American Academy of Business, $16(1), 65-70$.

McDougall, P. P., \& Oviatt, B. M. (2000). International entrepreneurship: the intersection of two research paths. Academy of Management Journal, 43(5), 902-906.

McDougall-Covin, P., Jones, M. V., \& Serapio, M. G. (2014). High-potential concepts, phenomena, and theories for the advancement of international entrepreneurship research. Entrepreneurship Theory and Practice, 38(1), 1-10.

McGrath, R. G., Mac Grath, R. G., \& MacMillan, I. C. (2000). The entrepreneurial mindset: Strategies for continuously creating opportunity in an age of uncertainty (Vol. 284). Harvard Business Press.

Miller, D., \& Friesen, P. H. (1983). Strategy-making and environment: the third link. Strategic Management Journal, $4(3), 221-235$

Milliken, F. J. (1990). Perceiving and interpreting environmental change: An examination of college administrators' interpretation of changing demographics. Academy of Management Journal, 33(1), 42-63.

Ministry of Industry, Mine and Trade( Republic of Islamic Of Iran) (2018) Information and Statistics. [online] http://en.mimt.gov.ir.

Mitchell, R. K., Smith, B., Seawright, K. W., \& Morse, E. A. (2000). Cross-cultural cognitions and the venture creation decision. Academy of Management Journal, 43(5), 974-993.

Morgan, R. E., \& Katsikeas, C. S. (1997). Export stimuli: Export intention compared with export activity. International Business Review, 6(5), 477-499.

Musteen, M., Francis, J., \& Datta, D. K. (2010). The influence of international networks on Internationalisation Speed and performance: A study of Czech SMEs. Journal of World Business, 45(3), 197-205.

Nocco, B. W., \& Stulz, R. M. (2006). Enterprise risk management: Theory and practice. Journal of Applied Corporate Finance, $18(4), 8-20$

Nonaka, I. (1994). A dynamic theory of organizational knowledge creation. Organization Science, 5(1), 14-37.

Nonally, J. C. (1978). Psychometric Theory (2th ed.). New York: Mac Graw Hill.

Nummela, N., Puumalainen, K., \& Saarenketo, S. (2005). International growth orientation of knowledge-intensive SMEs. Journal of International Entrepreneurship, 3(1), 5-18.

Nummela, N., Saarenketo, S., \& Puumalainen, K. (2004). A global mindset-a prerequisite for successful internationalization? Canadian Journal of Administrative Sciences/Revue Canadienne des Sciences de l'Administration, 21(1), 51-64.

Oviatt, B. M., \& McDougall, P. P. (2005a). Defining international entrepreneurship and modeling the speed of internationalization. Entrepreneurship Theory and Practice, 29(5), 537-553.

Oviatt, B. M., \& McDougall, P. P. (2005b). Retrospective: The internationalisation of entrepreneurship. Journal of International Business Studies, 36(1), 2-8. 
Oviatt, B. M., Shrader, R. C., \& McDougall, P. P. (2004). The internationalization of new ventures: A risk management model. In Theories of the Multinational Enterprise: Diversity, Complexity and Relevance (pp. 165-185). Emerald Group Publishing Limited.

Powell, E. E., \& Baker, T. (2014). It's what you make of it: Founder identity and enacting strategic responses to adversity. Academy of Management Journal, 57(5), 1406-1433.

Robertson, C., \& Chetty, S. K. (2000). A contingency-based approach to understanding export performance. International Business Review, 9(2), 211-235.

Roscoe, J. T. (1975). Fundamental Research Statistics for the Behavioural Sciences (2nd ed.). New York: Holt, Rinehart and Winston.

Samt Newspaper (2013) 10\% share of SME from exports. [online] https://www.smtnews.ir/industry/6617\%D8\%B3\%D9\%87\%D9\%85-\%DB\%B1\%DB\%B0-\%D8\%AF\%D8\%B1\%D8\%B5\%D8\%AF\%DB\%8C\%D8\%B5\%D9\%86\%D8\%A7\%DB\%8C\%D8\%B9-\%DA\%A9\%D9\%88\%DA\%86\%DA\%A9-\%D8\%A7\%D8\%B2\%D8\%B5\%D8\%A7\%D8\%AF\%D8\%B1\%D8\%A7\%D8\%AA.html. (in Persian)

Simon, M., Houghton, S. M., \& Aquino, K. (2000). Cognitive biases, Risk Perception, and venture formation: How individuals decide to start companies. Journal of Business Venturing, 15(2), 113-134.

Sitkin, S. B., \& Weingart, L. R. (1995). Determinants of risky decision-making behavior: A test of the mediating role of Risk Perceptions and propensity. Academy of Management Journal, 38(6), 1573-1592.

Terjesen, S., Hessels, J., \& Li, D. (2016). Comparative international entrepreneurship: A review and research agenda. Journal of Management, 42(1), 299-344

Vallaster, C. (2000). Conducting field research in Asia: Fundamental differences as compared to Western societies. Culture \& Psychology, 6(4), 461-476.

Wally, S., \& Baum, J. R. (1994). Personal and structural determinants of the pace of strategic decision making. Academy of Management Journal, 37(4), 932-956.

Weerawardena, J., Mort, G. S., Liesch, P. W., \& Knight, G. (2007). Conceptualizing accelerated internationalization in the born global firm: A dynamic capabilities perspective. Journal of World Business, 42(3), 294-306.

Westerberg, M., Singh, J., \& Häckner, E. (1997). Does the CEO matter? An empirical study of small Swedish firms operating in turbulent environments. Scandinavian Journal of Management, 13(3), 251-270.

Wiedersheim-Paul, F., Olson, H. C., \& Welch, L. S. (1978). Pre-export activity: The first step in internationalization. Journal of International Business Studies, 9(1), 47-58.

Wood, R., \& Bandura, A. (1989). Social cognitive theory of organizational management. Academy of Management Review, 14(3), 361-384.

Yli-Renko, H., Autio, E., \& Tontti, V. (2002). Social capital, knowledge, and the international growth of technology-based new firms. International Business Review, 11(3), 279-304.

Zahra, S. A., \& Hayton, J. C. (2008). The effect of international venturing on firm performance: The moderating influence of absorptive capacity. Journal of Business Venturing, 23(2), 195-220.

\section{Submit your manuscript to a SpringerOpen ${ }^{\circ}$ journal and benefit from:}

- Convenient online submission

- Rigorous peer review

- Open access: articles freely available online

- High visibility within the field

- Retaining the copyright to your article

Submit your next manuscript at $\boldsymbol{s p r i n g e r o p e n . c o m ~}$ 